\title{
The Implementation of Station Rotation and Flipped Classroom Models of Blended Learning in EFL Learning
}

\author{
Mahalli $^{1}$, Joko Nurkamto ${ }^{2}$, Januarius Mujiyanto ${ }^{3} \&$ Issy Yuliasri $^{3}$ \\ ${ }^{1}$ Semarang State University, Semarang, Indonesia \\ ${ }^{2}$ Sebelas Maret State University, Surakarta, Indonesia \\ ${ }^{3}$ Semarang State University, Semarang, Indonesia \\ Correspondence: Mahalli, Semarang State University, Semarang, Indonesia.
}

Received: September 30, 2019 Accepted: November 5, 2019 Online Published: November 7, 2019

doi: 10.5539/elt.v12n12p23

URL: https://doi.org/10.5539/elt.v12n12p23

\begin{abstract}
This research was conducted to analyze the implementation of blended learning. This study focused on the implementation Station Rotation and Flipped Classroom models of blended learning in academic writing course in English Education Study Program of UNISNU Jepara. Observation and interview were done to collect the data of the implementation of Station Rotation and Flipped Classroom model. The study found that station rotation was implemented in 3 cycles/rotations; 1) teacher led instruction, 2) independent work or ollaborative activities, and 3) online learning. Whereas flipped classroom was implemented in 2 steps; 1) lecturer share online assignment about the topic through SIAkad Unisnu Jepara, and 2) face-to-face meeting in the classroom. It also found that blended learning can facilitate the flexibiliy and make students learn more active and urge their curiousity.
\end{abstract}

Keywords: implementation, blended learning, academic writing, station rotation, flipped classroom

\section{Introduction}

Marsh (2012) states that learning a foreign language presents different challenges for different people in different contexts. From this point of view, various methods and approaches should be used to introduce new language, and a variety of classroom management techniques are employed to maximize practice of teaching and learning. She also states that students rarely have the opportunity to enter the world of the target language, despite our best efforts to introduce communicative, authentic language tasks into our classrooms.

Meanwhile the initial data of the observation of the EFL (English as Foreign Language) teaching done by the researcher shows that the majority of foreign language teaching still takes place in the classroom and the learners were very much dependent to their teachers and they got limited opportunities to engage with the target language. It is a problem of EFL teaching and learning, since opportunities to engage with the target language is very important for students to get real world of the target language. The situation is inline with idea of Marsh (2005) who says that achieving the optimum learning goal poses a significant challenge in most foreign language teaching situations where students have limited opportunities to actively engage in using the target language. Another problem is that it is very often that a teacher faces students who all have their own individual learning preferences, who come from different backgrounds, and who have different priorities and reasons for learning a language. Any group of students is often mixed from various ability with different goals or learning styles. Dealing with this situation Marsh (2012) claims that tasks that do not address a student's interests or learning style may fail to motivate, which is essential to language learning.

Realizing the challenges in EFL learning as mentioned above and referring to the data from the EFL classroom, Englsih Education Study Program of UNISNU Jepara have tried to solve the problem in EFL teaching and learning by implementing blended learning, the strategy that combining face-to-face and online learning (Dos, 2014), that promising some advantages as Rosenbaum (2012) claims that blended learning is now an established phenomenon in education, and institutions are increasing their effort to offer greater flexibility, more personalized learning, and greater learner satisfaction. Graham (2003) states that this strategy is more effective pedagogical practices. Blended learning increases the level of active learning strategies, peer-to-peer learning strategies, and learner-centered strategies used (Graham, 2003). 
Dealing with the model of blended learning implmentation, Staker and Horn (2012) classsify four models of blended learning; station rotation, lab rotation, individual rotation and flipped classroom models. These rotation models include any course or subject in which students rotate among learning modalities at least of which in online learning.

As a new strategy which has been implemented in the study program, it is very interesting to investigate how this strategy is implemented and how it provides benefit in EFL teaching and learning. It is also ineteresting to investigate it, because there have not been best practises of blended learning that can be models of implmentation, and also there is a gap between the practises and the literature that supports the implementation of blended learning in EFL learning, bacause lack of research conducted in this field.

\section{Method}

This study investigated some aspects of the implementation of blended learning strategy in teaching and learning of academic writing subject in English Education study program. They are; the modes, the models of integration, the distribution of learning content and objectives, the language teaching methods, the involvement of learning subjects, and the location. As it is a certain case happened in a certain subject or context, the same case may not happen to other subject or context, therefore, the study is categorized as a case study.

\subsection{Design}

This study use a single-case design. The case is the implementation of blended learning in teaching and learning within a broader context of English lectures at an institution of higher education. The unit of analysis is the teaching and learning of academic writing.

The unit of analysis was carefully chosen to reflect purposeful sampling used in qualitative research because intentionally sample a group of people that can best inform the researcher about the research problems under examination (Creswell, 2007). The choice of the unit of analysis was made based on certain consideration, that is the implementation of station rotation and flipped classroom models of blended learning in teaching and learning of academic writing.

\subsection{Technique of Data Collection}

Those aspects will be investigated and evaluated by doing classroom observation and interview about the implementation of blended learning model in teaching and learning academic writing.

\subsection{Instrument}

The instrument used to observe the implementation of blended learning is adopted from Neumeier (2005) which covers: a) the modes of blended learning implementation; b) the models of integration; c) the distribution of learning content and objectives; d) the language teaching methods used in teaching reading and writing; e) the involvement of learning subjects; f) the location where the process of teaching and learning takes place. While the interview was conducted with the leacturers and the students of academic writing class.

\section{Result}

Table 1. Parameters describing and conceptualizing a blended learning environment for language learning and teaching purposes*

\begin{tabular}{|c|c|c|}
\hline & Paremeter & Individual description \\
\hline \multirow[t]{3}{*}{1} & Modes & Focus on mode \\
\hline & & Distribution of modes \\
\hline & & Choice of modes \\
\hline \multirow[t]{2}{*}{2} & Model of integration & Sequencing of individual modes \\
\hline & & Level of integration \\
\hline 3 & $\begin{array}{l}\text { Distribution of learning content and objective and } \\
\text { assignment of purpose }\end{array}$ & Paralel or isolated \\
\hline 4 & Language teaching methods & $\begin{array}{l}\text { Use of teaching methods in each of the modes } \\
\text { employed }\end{array}$ \\
\hline 5 & Involvment of learning subjects (syudents, & Interactional patterns; individual vs collaborative \\
\hline
\end{tabular}


teachers)

\begin{tabular}{lll}
\hline teachers) & language learning \\
& Variety of teacher and learner roless \\
& Level of autonomy \\
& Location & Classroom, home, outdoors, computer romm \\
\hline
\end{tabular}

*adapted from Neumeier (2005).

\subsection{Observation}

Following is the data of the implementation of blended learning resulted from the observation done by the researcher using Neumeier's (2005) parameter.

\subsubsection{Modes}

Modes applied in the implementation of blended learning in academic writing are face-to-face and online. In this case, face-to-face is the lead mode, because most of the learning avtivities are face-to-face learning.

\subsubsection{Model of Integration}

The models of integration used in the teaching and learning of academic writing are station rotation model and flipped classroom model.

The station rotation model of integration covers three stages or cycles of activities or what so called station rotation. The three stages or cycles are; 1) small group instruction (teacher led instruction), 2) Independent work or ollaborative activities, and 3) online learning. The reseracher noted that the topic of the session is Characteristic of Academic Writing.

First stage (during first 30 minutes) group A conducted guided learning activities led by the lecturer. Lecturers explained the outline of the material, while 2) group B conducted online activities by browsing the internet related to lecture material which is the topic of lectures for 30 minutes by opening the web. The reseracher noted that at that time setudents browsed. http://www.writeawriting.com/academic-writing/characteristics-academic(characteristics of Academic Writing) 3) At the same time group C conducts discussions about the lecture topics being taught.

Second stage (second 30 minutes) During 30 minutes group $\mathrm{C}$ conducted discussion activities guided by the lecture. They discussed about the results of group discussion sessions in the first cycle. Group B conducted online activities by browsing the internet related to lecture material which was the topic of lectures for 30 minutes by opening the web. The researcher noted that at that time learners browssed. http://www.uefap.com/writing/feature/featfram.htm (Features of Academic Writing) At the same time group A carried out a group discussion about the topic of the lecture being taught.

Third stage (third 30 minutes). During 30 minutes group B conducted a discussion about the results of the online session which was guided by lecturer, group A conducted online activities by browsing the internet related to lecture material which was the topic of lectures for 30 minutes, by opening the web.The researcher noted the learners open the web: https://grammar.yourdictionary.com/word-definitions/definition-of-academic-writing.html (Definitions of Academic Writing).At the same time group C held an off line discussion discussing the topic of the lecture being taught. At the end of the activity the lecturer provides confirmation and clarification related to the topic of the lecture that has been discussed both through on line and through off line discussions.

Meanwhile in the flipped classroom model of integration, the learning activities are performed in two steps; 1) lecturer share online assignment about the topic, and 2) face-to-face meeting in the classroom.

Flipped classroom model is implemented in the following steps. The material was uploaded by the lecturer before the discussion in the classroom. The researcher noted at that time lecturer uploaded learning material taken from https://literaryterms.net/paraphrase/. The material was downloaded online through the SIAkad Unisnu Jepara. Students were given the task of finding information related to the material. It was in the form of word file and should be discussed in students group discussion consists of 4-5 students per group. After finding the lecture material, the web address and learning material were saved.

At the time of face-to-face meeting in class, lecturer invited each group to present the results of group discussin dealing with the assignment shared by the lecturer downloaded from Siakad Unisnu Jepara.. Presentation was carried out on line and off line (recorded), and continued with class discussions. At that moment the researcher noted. the first group group presented the topic from. 
https://examples.yourdictionary.com/examples-of-paraphrasing.html. Each group was given 30 minutes for presentation and discussion. At the end of the activity the lecturer provides confirmation and clarification related to the topic of the lecture that has been discussed both through on line and off line discussions.

\subsubsection{Distribution of Learning Content and Objectives}

Based on the observation, the researcher got the data that in station rotation model the content of learning was disttibuted parallelly in face-to-face and online learning simultaneously. The lecturer and students were discussing the concept of academic writing and at the same time the students parcticed how to develop a text about academic writing. While in flipped classroom model, the material was distributed online before class and the following meeting they discussed it face-to-face in the clasrroom.

\subsubsection{Methods}

From the data of observation the researher noted that the method used in classroom session are group discussion and class discussion. In station rotation model, the lecture distributed class into three groups. Each group has ten to twelve members. They discussed rotatively from one station to the other in the learning centre. The lecturer facilitate the learning session.

While in flipped classroom model, presentation and class discussion are used. The lecturer also distributed the class into six groups. Each group has 4-5 members. Each group should present the result of discussion. At the end of discussion session the lecturer gave confirmation and clarification.

\subsubsection{Types of Interraction and Roles of Lecturer and Learners}

Data collected from the observation showed thar there were three roles of lecturer in the learnings process; as a facilitator, an isntructor and a resource. While the roles of the learners were as recipients and as partners.

\subsubsection{Location}

The process of teaching and learning of academic writing observed by the researcher took place at two locations; 1) at home (or outside the classroom), where the students do online learning about the topic shared by the lecturer in flipped classroom model. 2) in the classroom and in the learning centre, where the students perform learning activities using station rotation model and the second step of flipped classroom model.

\subsection{Interview}

The reseacher interviewed the lecturer about the reason why he chose station rotation and flipped classroom models in teaching academic writing. He argued,

"......... (choosing the station rotation model) the strength of this activity (in sattion rotation) is that no student spends his time wastely and do not focus. Because they will later meet lecturers when online learning, they also have to discuss with friends, so that the relational learning experience is far more high impact And if the child (student) is accustomed to discussing (with friends), accustomed to online, then accustomed to discussing with lecturers (they) will certainly have a different experience to be more flexible.

Meanwhile the consideration why he chose flipped classroom was ...

“... I consider Flipped Classroom must not be abandoned. Flipped Classroom makes students ready to discuss in class because it is done before the class meeting with the teacher or lecturer"

The researcher also interviewed the students dealing with the pedagogical impacts of blended learning implementation. Based on the data of the interview it can be identified pedagogical impacts of the blended learning implementation in English Education study program, as follows in Table 2.

Table 2. Description of pedagogical impacts

\begin{tabular}{lll}
\hline No & Student & Description of pedagogical impacts \\
\hline 1 & Windi & Independent and Easily access material \\
2 & Dayanti & $\begin{array}{l}\text { Allows students to learn anywhere and at any time. Learning is not } \\
\text { boring. Not only is it glued to material from books but from other online } \\
\text { material }\end{array}$ \\
3 & Saifudin & Can improve the required information according to personal needs \\
4 & Umi Fitiriya & $\begin{array}{l}\text { Increase the power of knowledge and learning memory with learning } \\
\text { resources that are more interesting and efficient so as to support }\end{array}$ \\
\hline
\end{tabular}


face-to-face learning systems

$5 \quad$ Wika

$6 \quad$ Romdon

$7 \quad$ Fibri

$8 \quad$ Hardayanti

$9 \quad$ Siti
Making students become more active in seeking additional material on the internet so that it does not only depend on the explanation from the lecturer

Make it easier for students to do the learning process Make students active in independent learning without having to wait face to face with the lecturer. Get to know up to date English material

So not only depend on lecturers

Make students more independent and not dependent on lecturers. Facilitate the learning process

Is a supportive challenge for students to learn more.

\section{Discussion}

Based on the interview done by the reseacher it can be found the reason why choosing blended learning. As tt ws stated by the lecturers that flipped classromm and stattion rotation model was chosen because the two model give students a relational learning. Flipped classroom is implemented in order to give the chance and opportunity to prepare their lecture before they attend face-to-face learning in the classroom. Meanwhile, station rotation model was chosen because it can facilitate students to enhance and discuss deeeper about the material that the lecture has shared and uploaded online deeeper in face-to-face learning in group discussion led by the teacher. In brief it can be said that the two model were choosen because they can facilitate students learning individually as in online flipped classroom and collaborative learning during face-to-face learning as in station rotation cycles of learning. The idea is inline with Pierce and Fox (2013) who state that flipped classroom is to express students the concept that will be taught in class and urge their curiousity and interest for their in class activity. The strength of flipped classroom to make students ready to learn in class. It is also relefant with Ortega Gil and Arcos García, (2011) states that a great advantage of the Station Rotation model is that the teacher is allowed more flexibility in working with her students. The option of providing various types of learning opportunities for students multiplies the students' learning opportunities

The data resulted from the observations showed that the implementation of station rotation and flipped classroom models of blended learning were in line with the idea proposed by Stake and Horn (2013). Two modes were involved in the EFL learning of academic writing, they are face-to-face and online in which face-to-face was as lead mode. Neumeier (2005) states that the mode which guides learners and where they often spend most of the time is called the lead mode. Sequencing and negotiation of content is also done in the lead mode. Neumeir (2005: 168) states that the distribution of modes is an important parameter in the design of blended learning environments. It determines the use of modes dealing with all instructed learning processes and also shows the percentage of learning processes spent in individual modes. The way how to measure level of distribution is by considering the average amount of time deliberately spent in a particular mode (Grgurović, 2012). This point refers back to one of the criteria in determining lead mode, which is an estimate of the amount of time students spend working in a particular mode.

According to Neumeier (2005) there are two ways of incorporating learning content and objectives into a blended learning environment: parallel or isolated. Grgurović states that parallel distribution allows a certain language skill to be incorporated and practiced in both modes. In the case of parallel incorporation of a certain skill or an element of the language system (for example the teaching and learning of speaking skills) both modes are used for teaching and learning. With regard to course design, this means that the teaching of a specific language function (i.e. introducing a new topic into conversation) could be presented online and then practised in a face-to-face role-play or introduced in a face-to-face phase and then practised during a synchronous chat session. In the case of isolated incorporation, the skill would exclusively be acquired within one of the two major.

How the lecuture distributed the learning content and objectives in academic writing is parallel with the idea of Grgurović (2013) above. It can be proved from the result of the observation done by the reseracher that in station rotation model the content of learning was disttibuted parallelly in face-to-face and online learning simultaneously. The lecturer and students were discussing the concept of academic writing and at the same time the students parcticed how to develop a text about academic writing. While in flipped classroom model, the 
material was distributed isolated; online before class and the following meeting they discussed it face-to-face in the clasrroom.

Based on the result of the interview, it can be found that advantages of implementing station rotation and flipped calssroom are that the models can facilitate the students to be focus and interactive during learning. Blended learning makes it easier for students to do the learning process It also facilitates students active in independent learning without having to wait face to face with the lecturer The models can also facilitate the flexibiliy and make students free to ask confirmation and clarification of what they have not cleared about the learning material individually. It is in line with Stake and Horn (2012) that the setting allow the teacher to easily differentiate the instruction on students' needs. The station in which encorporates educational technology tools allow students to learn at their own pace and receive real time feedback to improve their material. Flipped classroom, on the other hand, is a restructure of classroom and at home activities (Bishop \& Verkleger, 2013). The strength of flipped classroom to make students ready to learn in class, as stated by the lecturer is also in line with Bogmann and Sams (2013) who state that flipped classroom allows students to actively participate in the class compared to traditional teaching method.

Further Ortega Gil and Arcos García, (2011) states that a great advantage of the Station Rotation model is that the teacher is allowed more flexibility in working with her students. The option of providing various types of learning opportunities for students multiplies the students' learning opportunities. For example, the educator can opt for small group or large group instruction, and the option to break the class into smaller groups allows for the possibility of having more time to work with smaller groups of students (Walne, 2012). By providing the various learning opportunities for students, they are allowed the opportunity to fully experience the concepts. Through this, students are better able to retain what is being taught and are also able to recall the information when needed (Bersin, 2004). The teacher has the opportunity to provide independent work or collaborative assignments (Staker \& Horn, 2012). In one pilot study using this model, the academic gains of the students involved were very encouraging. The overall number of students who performed at a proficient level after participating in this study increased their level by a minimum of $10 \%$ with some nearing $40 \%$ (Walne, 2012). This shows great promise for the successful use of this model in other classrooms, too.

Based on the findings and discussion about the implementation of station rotation and flipped calssroom models of blended learning in Academic Writing course of English Education Study Program of Unisnu Jepara, it can be concluded that the implementation of station rotation and flipped classroom models of blended learning in academic writing course is in line with the conceipt of Stake and Horn (2005). The mode of teaching and learning is combination of face-to-face and online learning in which face-to-face is the dominant mode. It can be seen from the level of integration where the presentage of face-to-face learning is higher that online learning. Meanwhile, the activities of learning is dominated by the learners. It can be proved from the teaching methods applied by the lecturer, the interaction patterns between the lecturer and the learners, and distribution of roles between the lecturer and the learner. In blended learning classroom, students are encouraged to explore and research and get information from many different areas.

The benefits of the implementation of these models of blended learning are they can facilitate the flexibiliy, in whcih the students can learn anytime, anywhere and make students learn individually on their own pace of learning. Besides that it can make the students ready with what will be taught in class and urge their curiousity and interest for their in - class activity. Blended learning makes it easier for students to do the learning process it can facilitate students active in independent learning without having to wait face to face with the lecturer.

\section{Acknowledgments}

I would like to express my deepest appreciation to all those who provided me the possibility to complete this article. A special gratitude I give to the Head of Study Program of English Education, Mr. Husni, who has permitted the researcher to conduct the research in this institution. I would also like to express my appreciation to the contributor of the data of the recent study, the lecturers, Mr. Muhlash Yusak and Mr. Taufiqurrahman for their contribution to be respondents of the interview.

\section{References}

Bath, D., \& Bourke, J. (2010). Getting Started with Blended Learning. Griffith Institute for Higher Education.

Bergmann, J., \& Sams, A. (2012). Flip Your Classroom: Reach Every Student In Every Class Every Day. Washington, DC: International Society for Technology in Education.

Bishop, J., \& Verleger, M. A. (2013). The Flipped Classroom: A Survey of the Research. 120th ASEE Annual Conference \& Exposition (Atlanta, Georgia). 
Creswell, J. W. (1994). Research Design: Qualitative and Quantitative Approaches. Sage.

Dos, B. (2014). Developing And Evaluating a Blended Learning Course. Faculty of Education, Zirve University, Turkey. https://doi.org/10.1080/09720073.2014.11891421

Grgurovic, M. (2013). Blended Learning in an ESL Class. A Case Study. CALICO Joutnal, 29(1). https://doi.org/10.11139/cj.29.1.100-117

Lee, S. H., \& Lee, J. H. (2007). Blended Learning Revisited, A New Approach to Foreign Language Education. Indiana University.

Marsh, D. (2012). Blended Learning, Creating Learning Oportunities for Language Learners. Cambridge University Press.

Neumeier, P. (2005). A Closer Look at Blended Learning - Parameters for Designing a blended learning Environment for Language Teaching and Learning. ReCALL, 17(2), 163-178. https://doi.org/10.1017/ S0958344005000224

Pierce, R., \& Fox, J. (2012). Vodcasts And Active-Learning Exercises In A Flipped Classroom Model Of A Renal Pharmacotherapy Module. American Journal of Pharmaceutical Education, 76(10), 176. https://doi.org/ 10.5688/ajpe7610196

Rosenbaum, P. (2012). E-Learning; A Study of Students' Attitudes and Learning Outcome When Using Blended Learning With Integration of Multimedia Instructions. Dissertation for the degree philosophy doctor (PhD) at the University of Bergen.

Staker, H. C., \& Horn, M. B. (2012). Classifying K-12 blended learning. Retrieved from Innosight Institute website www.innosightinstitute.org.

\section{Copyrights}

Copyright for this article is retained by the author(s), with first publication rights granted to the journal.

This is an open-access article distributed under the terms and conditions of the Creative Commons Attribution license (http://creativecommons.org/licenses/by/4.0/). 